\title{
Age- and hormone-related changes in vaginal smear patterns in the gray-tailed vole, Microtus canicaudus
}

\author{
Sandra L. Petersen* \\ Department of Zoology, Oregon State University, Corvallis, Oregon 97331, U.S.A.
}

\begin{abstract}
Summary. Female voles, Microtus canicaudus, exhibited age-related changes in vaginal smear patterns when isolated from males after weaning. Between 30 and 50 days of age, nearly all females exhibited persistently leucocytic vaginal smears. By 90-120 days, most females showed vaginal cyclicity with alternating predominance of leucocytes, nucleated epithelial cells or cornified epithelial cells. Most females examined between 150 and 200 days of age exhibited persistent vaginal cornification. The vaginal cyclicity seen in females between 90 and 120 days was not a reflection of cyclic ovulatory changes; plasma progesterone concentrations remained constant, regardless of age or vaginal smear pattern, and corpora lutea were never seen in unmated females. Although progesterone concentrations did not differ among vaginal smear patterns of 120-day-old females, plasma oestrogen values were highest in females exhibiting vaginal cornification.
\end{abstract}

\section{Introduction}

Vaginal epithelial cycles and the hormone changes associated with these cycles have been characterized for many spontaneously ovulating rodents (Feder, Goy \& Resko, 1967; Feder, Resko \& Goy, 1968; Leavitt \& Blaha, 1970; Lukaszewsska \& Greenwald, 1970; Challis, Heap \& Illingworth, 1971; Baranczuk \& Greenwald, 1973; Butcher, Collins \& Fugo, 1974; Campbell, Ryan \& Schwartz, 1976). In these rodents, the regular follicular cycles associated with spontaneous ovulation are reflected in predictable changes in plasma oestrogen and progesterone and, consequently, in changes in vaginal epithelium. Examination of a vaginal smear of a spontaneous ovulator therefore provides an indication of the hormonal state of the animal. For this reason, the terms used to describe vaginal smears (pro-oestrous, oestrous, dioestrous, and metoestrous) connote specific oestrogen and progesterone concentrations. Unlike spontaneously ovulating rodents, the reflexively ovulating microtine rodents (specifically lemmings and voles) exhibit considerable individual and species variability in vaginal smear patterns (Hasler, 1975; Sawrey \& Dewsbury, 1985). For example, voles reportedly exhibit persistent dioestrus with no evidence of oestrus (Bodenheimer \& Sulman, 1946), irregular oestrous periodicity with alternating smear types (Hoyte, 1955; Richmond \& Conaway, 1969; Kirkpatrick \& Valentine, 1970; Gray, Davis, Zerylnick \& Dewsbury, 1974; Milligan, 1974; MacFarlane \& Taylor, 1982) or persistent vaginal oestrus (Breed, 1967; Richmond \& Conaway, 1969; Milligan, 1974). Even though the terminology used to describe vaginal smears of voles is that established for spontaneous ovulators (Allen, 1922; Long \& Evans, 1922), none of the studies cited above have related the diverse vaginal smear patterns seen in voles to plasma concentrations of oestrogen and progesterone. Furthermore, no studies have systematically examined the factors contributing to this variability, although the studies cited above suggest that age at the time of examination may contribute to the variability in vaginal smear patterns reported for voles.

* Present address: Department of Physiology, School of Medicine, University of Maryland, Baltimore, MD 21201, U.S.A. 
For example, female Microtus guentheri housed away from males for 50 days after weaning show no vaginal oestrus (Bodenheimer \& Sulman, 1946), nor do most isolated female prairie voles, $M$. ochrogaster, show vaginal oestrus at 70-90 days of age (Hasler \& Conaway, 1973). In contrast, persistent vaginal oestrus, or irregular cycles, have been reported for isolated European field voles, $M$. agrestis (Breed, 1967), and isolated montane voles, M. montanus (Gray et al., 1974), after 90 days of age.

The present studies were undertaken to examine the relationship between vaginal smear patterns and age, and to determine oestrogen and progesterone levels associated with the diverse vaginal smear patterns seen in female gray-tailed voles, Microtus canicaudus.

\section{Materials and Methods}

\section{Animals}

The gray-tailed voles were from a colony maintained at Oregon State University in a wellventilated room with a controlled photoperiod $(16 \mathrm{~h}$ light: $8 \mathrm{~h}$ dark, lights off at 14:30 $\mathrm{h})$. The animals were housed in fibre-glass cages $(60 \times 15 \times 15 \mathrm{~cm})$ containing hardwood shavings and covered with hardware cloth. Purina rat chow, rabbit chow and water were available ad libitum. All voles were weaned at 18 days of age and housed in sexually-segregated groups of 2-3 siblings per cage until used in the studies. Males and females were housed in the same room but on different racks. All females in a particular study were housed on the same rack.

\section{Sampling}

Vaginal smears were obtained by gently flushing the vagina with warm tap water expelled from a micropipette. Smears were stained with toluidine blue and examined microscopically. Nucleated epithelial cells, leucocytes and cornified cells were counted in three fields at $\times 10$ magnification and the mean proportion of each of these cell types per smear was calculated.

Blood samples were taken from the retro-orbital sinus under light ether anaesthesia using heparinized capillary tubes. Samples were placed immediately on ice, then centrifuged. Plasma was stored at $-20^{\circ} \mathrm{C}$ until assayed for oestrogen or progesterone.

\section{Radioimmunoassays}

All antibodies were supplied by Dr G. D. Niswender (Fort Collins, CO).

Oestrogen. Oestrogen was assayed in $100 \mu \mathrm{l}$ samples using the procedures previously described (Korenman et al., 1974). The small volume of blood obtained from each female necessitated pooling samples from 2-3 females with similar smear patterns. Extraction with two 2-ml volumes of diethyl ether resulted in a mean extraction efficiency of $86 \pm 1 \cdot 8 \%$. Antibody No. 244 anti-oestradiol-6-BSA serum was used at a dilution of 1:450 000 and about 15000 d.p.m. $\left[2,4,6,7,16,17-{ }^{3}\right.$ H]oestradiol-17 $\beta$ (Amersham, Arlington Heights, IL) were added to each tube in the assay. All solutions were made up in $0.1 \%$ gelatin ( $\mathrm{pH} \mathrm{7.4)}$ within 1 week before use, filtered through $0.45 \mu \mathrm{m}$ filters (Sartorius Membranfilter, Hayward, CA). This procedure resulted in significant reductions in non-specific binding, compared with assays using unfiltered solutions or solutions prepared more than 1-2 weeks before use.

The range of the standard curve was from $2 \cdot 5$ to $250 \mathrm{pg}$. The $2 \cdot 5 \mathrm{pg}$ standard was always $2 \mathrm{~s}$.d. greater than 0 , and so the sensitivity of the assay was $2.5 \mathrm{pg}$ per tube or $25 \mathrm{pg} / \mathrm{ml}$ when $100 \mu \mathrm{l}$ samples were used. Oestradiol was consistently undetectable in water blanks. The slope of a dilution curve of $200,175,150,125,100$ and $75 \mu \mathrm{l}$ plasma samples and the slope of the standard curve did not differ, indicating parallelism. Known amounts of oestradiol were added to charcoal-stripped 
plasma, extracted and assayed. The correlation coefficient between expected and observed values was 0.998 , and the mean deviation of observed from expected values was $9.8 \%$. The intra-assay coefficient of variation (CV) for 8 replicates was $6 \cdot 1 \%$ and the interassay $\mathrm{CV}$ among 6 assays was $3 \cdot 6 \%$. Non-specific binding averaged $3 \cdot 5 \%$.

Although the antibody used is highly specific for oestradiol, it cross-reacts to a limited degree $(<3 \%)$ with oestrone (Korenman et al., 1974). Insufficient plasma was available for chromatography to determine whether significant concentrations of oestrone were being measured in addition to oestradiol; therefore, values are reported as total oestrogens.

Progesterone. Samples of plasma pools from animals of various ages and showing different vaginal smear patterns were assayed for progesterone after celite chromatography (Weisz \& Ward, 1980), or were assayed without chromatography. No differences were seen between values obtained using these two methods, and so all samples were assayed without chromatography.

Progesterone was assayed in $25 \mu \mathrm{l}$ duplicate samples of plasma using general procedures previously described (Koligian \& Stormshak, 1977). Charcoal precipitation was used to separate bound from free steroids. All solutions were made in $0.01 \mathrm{M}-\mathrm{PBS}$ with $0.1 \%$ gelatin $(\mathrm{pH} 7 \cdot 0$ ).

For progesterone assays, extraction with two 2-ml volumes of diethyl ether resulted in a mean extraction efficiency of $80 \cdot 0 \pm 3 \cdot 2 \%$. Anti-progesterone-11-BSA serum (No. 337) was used at a dilution of 1:3750 and about 10000 d.p.m. $\left[1,2,6,7-{ }^{3} \mathrm{H}\right]$ progesterone (New England Nuclear, Boston, MA) were used per tube. The range of the standard curve was $7 \cdot 8-1000 \mathrm{pg}$. The $7 \cdot 8 \mathrm{pg}$ standard was always 2 s.d. greater than 0 , making the sensitivity of the assay $7.8 \mathrm{pg} /$ tube or $312 \mathrm{pg} / \mathrm{ml}$ in $25 \mu \mathrm{l}$ samples. Progesterone was never detected in water blanks.

The slope of a dilution curve of $200,100,50,25$ and $10 \mu$ l plasma did not differ from that of the standard curve. Known amounts of progesterone were added to charcoal-stripped plasma, extracted with ether and assayed. The mean deviation of observed from expected values was $5.6 \%$, and the correlation coefficient between expected and observed values was 0.999 . The intra-assay $\mathrm{CV}$ for 8 replicates of a plasma pool was $4.0 \%$ and the interassay CV for 10 assays was $6.8 \%$.

\section{Study 1: age and vaginal smear patterns}

To determine whether vaginal smear patterns change with age, smears were obtained daily $(12: 00 \mathrm{~h})$ for 14 days from isolated females of the following age groups: (A) 30-50 days $(\mathrm{N}=41)$, (B) 90-120 days $(\mathrm{N}=41)$ and $(\mathrm{C}) 150-200$ days $(\mathrm{N}=50)$. Animals were assigned to age-treatment groups across litter and all samples were obtained during the same period of 1 month. During the 2 weeks of examination, animals were left in the same cages and bedding was not changed, because of the possibility that such a disturbance could result in vaginal smear changes as suggested by Richmond \& Conaway (1969).

\section{Study 2: oestrogen and progesterone concentrations in females with different vaginal smear patterns}

To determine whether the different vaginal smear patterns of cyclic female voles reflect changes in hormone levels similar to those seen in cyclic rats or mice, a group of 85 females 120 days of age was examined. Vaginal smears and blood samples were obtained from all animals and samples were analysed for oestrogen or progesterone. Vaginal smear types were categorized into the three types most commonly seen: $\mathrm{L}=$ predominantly leucocytes with occasional epithelial cells (similar to dioestrous smears in mice; Allen, 1922), $\mathrm{N}=$ nucleated epithelial cells and mucus (similar to prooestrous smears in mice), $\mathrm{C}=$ predominately cornified epithelial cells (similar to oestrous smears in mice). 


\section{Study 3: progesterone concentration, age and vaginal smear patterns}

This study was done to verify that these female voles do not go through a period of life during which ovulation occurs spontaneously. Because progesterone concentrations are known to increase in female voles after mating-induced ovulation (S. L. Petersen, unpublished), blood samples for this hormone were taken from a total of 95 females aged 30,45, 60, 75, 90,120 and 150 days showing different vaginal smear patterns. In addition, ovaries of all females were examined macroscopically for the presence of corpora lutea. For this study vaginal smears were again examined and quantitated as previously described. They were categorized as follows: $\mathrm{L}=$ predominately leucocytic ( $>50 \%$ ) with occasional epithelial cells, $\mathrm{N}=$ predominately nucleated epithelial cells $(>50 \%)$, and $\mathrm{C}=$ cornified cells only. Smear patterns and progesterone concentrations at various ages were compared.

It seemed possible that subtle changes in vaginal smear patterns may reflect differences in progesterone values. For this reason, the vaginal smear categories described above were subdivided and progesterone concentrations were measured in an additional 60 females between 110 and 130 days of age. The subdivided categories were as follows: $L_{1}=$ predominantly leucocytes with occasional epithelial cells, $\mathrm{L}_{2}=$ leucocytes, epithelial cells and cornified cells present in similar numbers, $\mathrm{N}=$ nucleated epithelial cells and mucus, $\mathrm{C}_{1}=$ cornified cells and leucocytes, $\mathrm{C}_{2}=$ cornified cells, nucleated epithelial cells and leucocytes, and $\mathrm{C}_{3}=$ cornified cells only. Blood samples were assayed for progesterone and values were compared amongst females in the six categories.

\section{Data analysis}

The results were analysed using one-way or two-way ANOVA to determine differences amongst means of hormone concentrations. Bonferroni's $t$ tests were used to determine differences between specific means when appropriate. Differences in proportions of animals exhibiting particular vaginal smear patterns were analysed by $\chi^{2}$ tests.

\section{Results}

\section{Study 1}

The data describing age-related vaginal smear patterns are presented in Fig. 1. All females examined exhibited vaginal perforation. More than $95 \%$ of females in the $30-50$-day age group persistently displayed leucocytic smears. The incidence of persistent leucocytic smears decreased with age and that of persistent cornification increased with age. In females examined between the ages of 90 and 120 days of age, the frequency of cornified smears increased in individual animals during the 2nd week of examination. About two-thirds of females between 90 and 110 days of age showed vaginal cycles. Smear types similar to those reported by Allen (1922) for the mouse were seen in the vole; however, the sequence was not regular and not comparable to that of mice. For example, pro-oestrous-like smears (predominantly nucleated epithelial cells) infrequently preceded, and sometimes followed, vaginal oestrus (cornified cells); metoestrous-like smears (cornified epithelial cells and leucocytes) occurred both before and after oestrous smears. In 'cyclic' female voles, leucocytic predominance generally lasted for 1-3 days and alternated with 1-3 days of cornified smears or 1-2 days of nucleated epithelial cell smears. By 150-200 days, two-thirds of females showed persistent vaginal cornification.

\section{Study 2}

The results of this study are presented in Table 1. Oestrogen concentrations were significantly higher in females with predominantly cornified cells than in females with either leucocytic or 


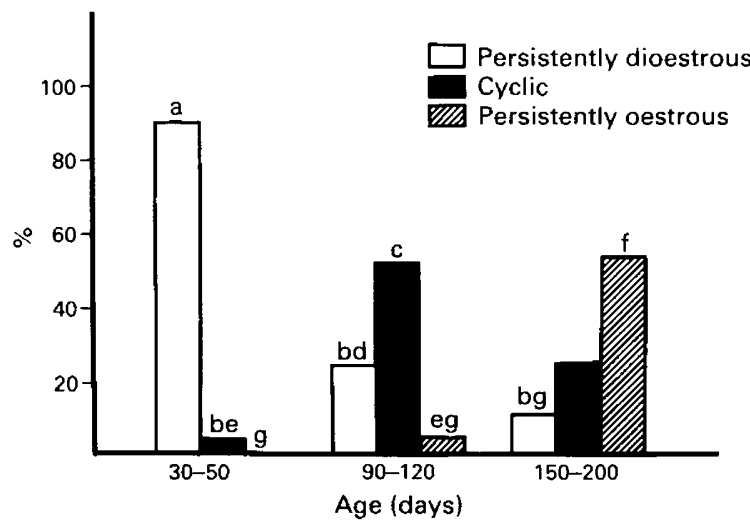

Fig. 1. Age-related changes in vaginal smear patterns in female gray-tailed voles. $a-b$, $P<0.001 ; \mathrm{c}-\mathrm{d}, P<0.05 ; \mathrm{c}-\mathrm{e}, P<0.001 ; \mathrm{f}-\mathrm{g}, P<0.001$.

Table 1. Plasma steroid concentrations in female gray-tailed voles exhibiting different vaginal smear patterns at 120 days of age

\begin{tabular}{lrcc}
\hline & \multicolumn{3}{c}{ Vaginal smear pattern } \\
\cline { 2 - 4 } Hormone & $\mathrm{L}$ & $\mathrm{N}$ & $\mathrm{C}$ \\
\hline Oestrogen $(\mathrm{pg} / \mathrm{ml})$ & $56.06 \pm 5.58(14)$ & $52.99 \pm 3.97(9)$ & $* 133.56 \pm 17.33(9)$ \\
Progesterone $(\mathrm{ng} / \mathrm{ml})$ & $6.80 \pm 0.66(15)$ & $7.60 \pm 0.24(12)$ & $8.23 \pm 0.97(12)$ \\
\hline
\end{tabular}

Values are mean \pm s.e.m. for the no. of pools of 2-3 females (oestrogen) and the no. of individual samples (progesterone).

$\mathrm{L}=$ predominantly leucocytic smears; $\mathrm{N}=$ predominantly nucleated epithelial smears; $\mathrm{C}=$ predominantly cornified cells.

${ }^{*} P<0.01$ compared to values for $\mathrm{L}$ and $\mathrm{N}$.

Table 2. Plasma progesterone concentrations $(\mathrm{ng} / \mathrm{ml})$ in female gray-tailed voles exhibiting different vaginal smear patterns at different ages

\begin{tabular}{|c|c|c|c|}
\hline \multirow[b]{2}{*}{ Age (days) } & \multicolumn{3}{|c|}{ Vaginal smear patterns } \\
\hline & $\mathrm{L}$ & $\mathbf{N}$ & $\mathrm{C}$ \\
\hline 30 & $4 \cdot 10 \pm 0 \cdot 89(5 / 5)$ & $-(0 / 5)$ & $-(0 / 5)$ \\
\hline 45 & $5.91 \pm 0.74(9 / 9)$ & $-(0 / 9)$ & $-(0 / 9)$ \\
\hline $75-90$ & $6.53 \pm 0.42(25 / 53)$ & $6.99 \pm 0.51(15 / 53)$ & $6.33 \pm 0.43(13 / 53)$ \\
\hline 120 & $6.48 \pm 0.89(5 / 21)$ & $8.00 \pm 0.77(7 / 21)$ & $5.92 \pm 0.64(9 / 21)$ \\
\hline 150 & $8.65 \pm 0.85(2 / 7)$ & $7.00 \pm 0.40(2 / 7)$ & $5.30 \pm 1.60(3 / 7)$ \\
\hline \multicolumn{4}{|l|}{ All ages } \\
\hline combined & $6 \cdot 28 \pm 0.33(46 / 95)$ & $7.29 \pm 0.39(24 / 95)$ & $6.11 \pm 0.39(25 / 95)$ \\
\hline
\end{tabular}

Values are mean \pm s.e.m. The proportion of females exhibiting particular vaginal smear patterns are given in parentheses. $\mathrm{L}=$ predominantly leucocytic smears; $\mathrm{N}=$ predominantly nucleated epithelial smears; $\mathrm{C}=$ predominantly cornified cells. 
nucleated epithelial smear patterns. Progesterone concentrations did not differ amongst females showing any of the three smear patterns observed.

\section{Study 3}

There were no age-associated differences in progesterone or differences in progesterone concentrations associated with vaginal smear patterns (Table 2). Therefore, data from all age groups were combined for each vaginal smear patterns so that progesterone concentrations could be compared for specific vaginal smear patterns. No differences in plasma progesterone values were seen amongst females exhibiting the three major vaginal smear patterns, or amongst females showing any of the six subcategories of vaginal smear patterns (mean \pm s.e.m. for $\mathrm{N}$ individuals sampled: $6.79 \pm 0.48(\mathrm{~N}=20)$ for $\mathrm{L}_{1}$ smears; $7.01 \pm 0.99(\mathrm{~N}=9)$ for $\mathrm{L}_{2} ; 8.34 \pm 0.98(\mathrm{~N}=5)$ for $\mathrm{N} ; 7.83 \pm 1.28(\mathrm{~N}=3)$ for $\mathrm{C}_{1} ; 6.37 \pm 0.49(\mathrm{~N}=6)$ for $\mathrm{C}_{2} ; 7 \cdot 15 \pm 0.69(\mathrm{~N}=17)$ for $\left.\mathrm{C}_{3}\right)$. No corpora lutea were found in females displaying any of the vaginal smear patterns described.

\section{Discussion}

All of the vaginal smear patterns previously described for other species of voles were exhibited in this study by female gray-tailed voles $(M$. canicaudus) isolated from males for $3-5$ months after weaning. The variability in vaginal smear patterns seen in these voles was related to age. Before 50 days of age, females showed persistently leucocytic vaginal smears, but after 90 days, oestrus occurred periodically. By 150-200 days, nearly all females displayed persistent vaginal oestrus. Although females showed evidence of irregular vaginal cyclicity when examined between 90 and 120 days of age, the cycles were not a reflection of cyclic ovulatory changes.

The cellular associations in vaginal smear patterns of 'cyclic' female voles at 90-120 days of age were the same as those described for spontaneously-ovulating rodents (Allen, 1922; Long \& Evans, 1922). However, vaginal smear changes in 'cyclic' voles were not associated with the same ovarian hormone changes that occur during the oestrous cycles of spontaneous ovulators. For example, nucleated epithelial cell smears in voles (pro-oestrous smears in rats and mice) were not associated with peak levels of oestrogen as they are in rats (Butcher et al., 1974); in voles, peak oestrogen values were associated with vaginal cornification (oestrous smears in rats). Furthermore, female voles, unlike female rats, have similar oestrogen and progesterone concentrations when displaying metoestrous-like, pro-oestrous-like and dioestrous-like vaginal smears.

The finding that similar vaginal smear patterns in voles and rats are associated with different oestrogen and progesterone levels indicates that vaginal smear patterns in voles represent ovarian events different from those of spontaneously ovulating rodents. Changes in vaginal smear patterns in rats and mice reflect regular follicular cycles; as follicles develop, oestrogen levels rise and trigger an ovulatory surge release of luteinizing hormone. After ovulation, oestrogen levels are low and progesterone is secreted by corpora lutea. In contrast, vaginal changes in voles appear to be nonovulatory; corpora lutea were not observed in any females between the ages of 90 and 120 days of age when irregular vaginal epithelial cycles were seen. Furthermore, progesterone concentrations in plasma did not differ amongst females with different vaginal conditions at any age. It is likely that vaginal 'cycles' in voles may result from irregular, nonovulatory follicular changes similar to those described for another reflex ovulator, the rabbit. In rabbits, some follicles are maturing while others are undergoing atresia (Hill \& White, 1933). Ovaries of unmated gray-tailed voles older than 90 days contain similar numbers of developing, mature, and atretic follicles, whatever types of vaginal smear patterns are exhibited (S. L. Petersen, unpublished). Similarly, in a closely related species, Pitymys subterraneus (another reflex ovulator), the number of large ovarian follicles per female is similar among females, regardless of vaginal smear patterns displayed (Jemiolo, 1983). 
Oestrogen concentrations have not been reported for any other microtine. The oestrogen values of female gray-tailed voles are generally higher than those reported for other rodents (Challis et al., 1971; Butcher et al., 1974; McCormack \& Greenwald, 1974; Shaikh \& Shaikh, 1975; Campbell et al., 1976). However, maximum levels of oestrogens in a related species, the hamster, were similar to those of the vole (Baranczuk \& Greenwald, 1973). In addition, unpublished work by D. Dluzen. (personal communication) shows that oestrogen levels of female $M$. ochrogaster are similar to those of $M$. canicaudus.

Mean progesterone concentrations in female gray-tailed voles isolated from males ranged between 4.1 and $8.6 \mathrm{ng} / \mathrm{ml}$, regardless of age or vaginal smear pattern. Progesterone values have been reported for two other female microtines, $M$. arvalis and montane voles, $M$. montanus. Unlike $M$. canicaudus and $M$. montanus females, $M$. arvalis females are reported to ovulate spontaneously (Delost, 1955). The range of progesterone concentrations in $M$. arvalis is $1-8 \mathrm{ng} / \mathrm{ml}$ depending on the stage of the oestrous cycle (Dobrowolska \& Gromadzka, 1978). The highest progesterone levels appeared at metoestrus, and the lowest at pro-oestrus. The absolute values of progesterone in $M$. arvalis are similar to those of $M$. canicaudus. In contrast, progesterone values reported for $M$. montanus (9-14 ng/ml) (Gray, Davis, Kenney \& Dewsbury, 1976) were higher than those of $M$. canicaudus. Unlike $M$. canicaudus, $M$. montanus females displaying cornified vaginal smears have higher progesterone concentrations than do those with leucocytic smears.

The age-related changes in vaginal smear patterns observed in voles in these studies are also seen in ageing female rats. Female rats also become persistently oestrous after previously exhibiting cycles; however, it is unlikely for several reasons that these changes in ageing female rats are analogous to changes described for female voles. First, the vaginal cycles exhibited by female voles do not result from the same ovulation-related changes in hormones that produce vaginal cycles in female rats. Secondly, 'cyclic' female voles do not mate or reproduce as readily as persistently oestrous females (Petersen, 1985). In contrast, maximum fertility occurs during the period of cyclicity in rats, and the period of persistent oestrus marks the cessation of cyclic reproductive activity (Everett, 1939; Huang \& Meites, 1975; Lu, Hopper, Vargo \& Yen, 1979; Steger, Huang, Chamberlain $\&$ Meites, 1980). Finally, the onset of persistent oestrus in voles in this study occurred at about 3-5 months. This is fairly early in their reproductive lives because voles in the laboratory reproduce for 12-16 months (S. L. Petersen, unpublished). In contrast, the onset of persistent oestrus in rats occurs towards the end of their reproductive lives, at 10-20 months of age (Steger et al., 1980). It is therefore unlikely that the stages observed in female voles isolated from males represent reproductive senescence. Rather, it appears that maturation is delayed in females isolated from males when reared in the laboratory, because female gray-tailed voles housed with unfamiliar males from weaning can mate and produce offspring before 1 month of age (Hagen \& Forslund, 1979).

This research was supported by grants from Sigma Xi and the Oregon State University Department of Zoology Research Fund. I thank Dr Frank L. Moore for support and comments on early drafts of the manuscript and Dr Thomas Zoeller for help with the project.

\section{References}

Allen, E. (1922) The oestrous cycle in the mouse. Am. J. Anat. 30, 297-371.

Baranczuk, R. \& Greenwald, G.S. (1973) Peripheral levels of estrogen in the cyclic hamster. Endocrinology $\mathbf{9 2}$, $805-812$.

Bodenheimer, F.S. \& Sulman, F. (1946) The oestrous cycle of Microtus guentheri D. and A. and its ecological implications. Ecology 27, 255-256.

Breed, W.G. (1967) Ovulation in the genus Microtus. Nature, Lond. 214, 826.
Butcher, R.L., Collins, W.E. \& Fugo, N.W. (1974) Plasma concentrations of LH, FSH, prolactin, progesterone and estradiol- $17 \beta$ throughout the 4-day estrous cycle of the rat. Endocrinology 94, 1704-1708.

Campbell, C.S., Ryan, K.D. \& Schwartz, N.B. (1976) Estrous cycles in the mouse: relative influence of continuous light and the presence of a male. Biol. Reprod. 14, 292-299.

Challis, J.R.G., Heap, R.B. \& Illingworth, D.V. (1971) Concentrations of oestrogen and progesterone in 
the plasma of nonpregnant, pregnant and lactating guinea-pigs. J. Endocr. 51, 333-345.

Delost, P. (1955) Development sexual normal du campagnol des champs (Microtus arvalis P.), de la naissance a l'age adulte. Archs Anat. microsc. Morph. exp. 44, 150-190.

Dobrowolska, A. \& Gromadzka, J. (1978) Relationship between haematological parameters and progesterone blood concentration in different stages of estrous cycle in common vole, Microtus arvalis. Comp. Biochem. Physiol. 61A, 483-485.

Everett, J.W. (1939) Spontaneous persistent estrus in a strain of albino rats. Endocrinology 25, 123-127.

Feder, H.H., Goy, R.W. \& Resko, J.A. (1967) Progesterone concentrations in the peripheral plasma of cyclic rats. J. Physiol., Lond. 191, 136-137p.

Feder, H.H., Resko, J.A. \& Goy, R.W. (1968) Progesterone concentrations in the arterial plasma of guineapigs during the oestrous cycle. J. Endocr. 40, 505-513.

Gray, G.D., Davis, H.N., Zerylnick, M. \& Dewsbury, D.A. (1974) Oestrus and induced ovulation in montane voles. J. Reprod. Fert. 38, 193-196.

Gray, G.D., Davis, H.N., Kenney, A.McM. \& Dewsbury, D.A. (1976) Effect of mating on plasma levels of LH and progesterone in montane voles (Microtus montanus). J. Reprod. Fert. 47, 89-91.

Hagen, J.B. \& Forslund, L.G. (1979) Comparative fertility of four age classes of female gray-tailed voles, Microtus canicaudus, in the laboratory. J. Mammal. 60, 834-837.

Hasler, J.F. (1975) A review of reproduction and sexual maturation in the microtine rodents. The Biologist 57, 52-86.

Hasler, M.J. \& Conaway, C.H. (1973) The effect of males on the reproductive state of female Microtus ochrogaster. Biol. Reprod. 9, 426436.

Hill, M. \& White, W.E. (1933) The growth and regression of follicles in the oestrous rabbit. J. Physiol, Lond. $\mathbf{8 0}$, 174-179.

Hoyte, H.M.D. (1955) Observations on reproduction in some small mammals of arctic Norway. J. Anim. Ecol. 24, 412-425.

Huang, H.H. \& Meites, J. (1975) Reproductive capacity of aging female rats. Neuroendocrinology 17, 289-295.

Jemiolo, B. (1983) Ovulation and fertilization in the vole Pitymys subterraneus. Biol. Reprod. 28, 523-527.

Kirkpatrick, R.L. \& Valentine, G.L. (1970) Reproduction in captive pine voles, Microtus pinetorum. J. Mammal. 51, 779-795.

Koligian, K.B. \& Stormshak, F. (1977) Nuclear and cytoplasmic estrogen receptors in ovine endometrium during the estrous cycle. Endocrinology 101, 524-533.

Korenman, S.G., Stevens, R.H., Carpenter, L.A., Robb, M., Niswender, G.D. \& Sherman, B.M. (1974) Estradiol radioimmunoassay without chromatography: procedure, validation and normal values. J. clin. Endocr. Metab. 38, 718-720.

Leavitt, W.W. \& Blaha, G.C. (1970) Circulating progesterone levels in the golden hamster during the estrous cycle, pregnancy and lactation. Biol. Reprod. 3, 353-361.

Long, J.A. \& Evans, H.M. (1922) The oestrous cycle in the rat and its associated phenomena. Mem. Univ. Calif. 6, 1-113.

Lu, K.H., Hopper, B.R., Vargo, T.M. \& Yen, S.S.C. (1979) Chronological changes in sex steroid, gonadotropin and prolactin secretion in aging female rats displaying different reproductive states. Biol. Reprod. 21, 193-203.

Lukaszewska, J.H. \& Greenwald, G.S. (1970) Progesterone levels in the cyclic and pregnant hamster. Endocrinology 86, 1-9.

MacFarlane, J.D. \& Taylor, J.M. (1982) Pregnancy and reproductive performance in the Townsend's vole, Microtus townsendii (Bachman). J. Mammal. 63, 165-168.

McCormack, J.T. \& Greenwald, G.S. (1974) Progesterone and oestradiol-17\% concentrations in peripheral plasma during pregnancy in the mouse. J. Endocr. 62, 101-107.

Milligan, S.R. (1974) Social environment and ovulation in the vole, Microtus agrestis. J. Reprod. Fert. 41, $35-47$.

Petersen, S.L. (1985) The role of perinatal androgens in the development of neuroendocrine and behavioral characteristics of the gray-tailed vole, Microtus canicaudus. Ph.D. dissertation, 166 pp, Oregon State University.

Richmond, M. \& Conaway, C.H. (1969) Induced ovulation and oestrus in Microtus ochrogaster. J. Reprod. Fert., Suppl. 6, 357-376.

Sawrey, D.K. \& Dewsbury, D.A. (1985) Control of ovulation, vaginal estrus and behavioral receptivity in voles (Microtus). Neurosci. Biobeh. Rev. 9, 563-571.

Shaikh, A.A. \& Shaikh, S.A. (1975) Adrenal and ovarian steroid secretion in the rat estrous cycle temporally related to gonadotropins and steroid levels found in peripheral plasma. Endocrinology 96, 37-44.

Steger, R.W., Huang, H.H., Chamberlain, D.S. \& Meites, J. (1980) Changes in control of gonadotropin secretion in the transition period between regular cycles and constant estrus in aging female rats. Biol. Reprod. 22, 595-603.

Weisz, J. \& Ward, I.L. (1980) Plasma testosterone and progesterone titers of pregnant rats, their male and female fetuses, and neonatal offspring. Endocrinology 106, 306-316.

Received 19 November 1985 